\title{
パーフルオロカーボン液中インパルス沿面放電の進展特性
}

$\begin{array}{llllllll}\text { 正 } & \text { 中尾 } & \text { 好隆 } & \text { (室蘭工業大学) } & \text { 学生員 } & \text { 脇本 } & \text { 聖 } & \text { (室蘭工業大学) } \\ \text { 正 } & \text { 員城 克徳 } & \text { (明電舎) } & \text { 正 } & \text { 員 } & \text { 伊藤 秀範 } & \text { (室蘭工業大学) } \\ \text { 正 員 酒井 洋輔 } & \text { (北海道大学) } & \text { 正員 } & \text { 田頭 博昭 } & \text { (北海道工業大学) }\end{array}$

\section{Propagation Characteristics of Impulse Creepage Discharge in Perfluorocarbon Liquid}

Yoshitaka Nakao, Member, Kiyoshi Wakimoto, Student Member (Muroran Institute of Technology),

Katsunori Miyagi, Member (Meidensha Co.), Hidenori Itoh, Member (Muroran Institute of Technology),

Yosuke Sakai, Member (Hokkaido University), Hiroaki Tagashira, Member (Hokkaido Institute of Technology)

\begin{abstract}
In this paper, the propagation characteristics of a creepage discharge on the surface of a solid insulator with a back electrode in perfluorocarbon liquid under an impulse voltage application are investigated. The propagation process is observed in detail by using a high-speed schlieren optical technique, and simultaneously waveforms of a current and a charge are also measured. Consequently, the polarity effect of the streamer propagation and the positive streamer which propagates stepwise can be seen. The latter is concurrent with the sparse current pulse which corresponds to the charge step-variation. These results are compared with ones obtained in transformer oil.
\end{abstract}

キーワード : 油中沿面放電, パーフルオロカーボン液, シュリーレン法

\section{1. まえがき}

都市部における電力需要の増加に伴う変圧器の高電圧・ 大容量化の要求とともに，都市防災と環境調和の観点から 変圧器の不然化および小型化が強く要求されている。不然 化を目的とした小・中容量変圧器としては, 従来の油入変 圧器に代わって $\mathrm{SF}_{6}$ ガス絶緣変圧器が既に開発・実用化 の段階にあり，これによって防災，設備の縮小，保守の簡 素化等, 多くの成果が得られている。しかし, 大容量変圧 器に対しては, $\mathrm{SF}_{6}$ ガスを冷媒とする方式では冷却性能の 点で対応できず, 依然として油入変圧器が志向されており, 例えばパーフルオロカーボン液（PFC 液）の如き優れた 冷媒による液冷却式ガス絶縁変圧器, 液浸方式複合絶縁変 圧器等の開発研究, 試作検郡が行われている(1-4)。

PFC 液の絶縁破壊に関する研究は比較的新しく，変圧 器油ほど多くの研究が行われていないのが現状である。 PFC 液に関するこれまでの研究は主に絶縁破壊特性に重 点を置いて行われており, 絶縁破壊の進展過程については ほとんど報告されておらず, $\mathrm{PFC}$ 液の絶縁性能, 絶縁破 烄機構などの詳細については必ずしも明らかにされていな W(4-11)。従って, PFC 液を変圧器の絶縁・冷却用の媒体 として適用するためには，PFC 液自身およびこれと固体 絶縁物とが共存する場合の複合絶縁構成における絶縁破壊 の進展過程について詳細に把握することが必要である。

著者らはこれまで, フッ素 F の存在に起因すると考え られる特異な物理化学的性質を有する PFC 液を取り上げ, 液中に配置した針電極一固体䋓緣物一背後平板電極系にお
けるインパルス沿面放電の進展過程について調査し, 同条 件における変圧器油中沿面放電 ${ }^{(12)}$ と比較しながら種々検 郡を行ってきた ${ }^{(13,14)}$ 。本研究では, 高速シュリーレン法 による沿面放電の観測および電流・電荷波形の測定を同時 に行った。本論文は以上の結果をまとめたものであるが， 特に正極性インパルス電圧印加時に顥著に認められるスト リーマ状密度変化（ストリーマ）のステップ進展について 詳細に検討されている。

\section{2. 試料夜体}

実験で用いた PFC 液はパーフルオロオクタン $\left(\mathrm{C}_{8} \mathrm{~F}_{18}\right.$, 分子量 438.06）を主成分とする不活性液体である。表 1 は PFC 液と変圧器油（JIS 2 号）との物性比較を示す。

PFC 液は一般的に次のような特徵を有する：(1) 不燃, (2) 沸点が低い, (3) 密度大, (4) 動粘度小, (5) 冷却性能が 非常に良い，(6) 平等電界下で変圧器油と同程度の絶縁耐 力が得られる, (7) $\mathrm{SF}_{6}$ ガスを溶解し易い。

これらの性質は F や C-F 結合の性質 (15)に起因し, 特に $\mathrm{F}$ の大きなイオン化エネルギーと強い電子親和力は, $\mathrm{PFC}$ 液中放電に大きな影響を与えるものと考えられる。

\section{3. 実験装置および方法}

図 1 は実験システムの構成を示し，基本的には前報 ${ }^{(16)}$ と同様である。全ての実験は室温大気圧下で行るれ，イン パルス電死発生回路のコンデンサを充電後, トリガ用マニ ュアルボタン $\mathrm{MB}$ を押してキセノンフラッシュ $\mathrm{XeF}$ を閃 光させることにより開始する。電流 $i(t)$ および電荷 $q(t)$ の 
表 1. PFC 液と変玨器油の物性 $\left(25^{\circ} \mathrm{C}, 1 \mathrm{~atm}\right)$

Table 1. Properties of PFC liquid and transformer oil

\begin{tabular}{|c|c|c|c|c|c|}
\hline \multirow{2}{*}{\multicolumn{2}{|c|}{$\begin{array}{l}\text { 項目 } \\
\text { 主成分 }\end{array}$}} & 単位 & PFC液 & 変圧器油 & 変圧器油と比較した PFC 液の特徽 \\
\hline & & $=$ & $\mathrm{C}_{8} \mathrm{~F}_{18}$ & $\mathrm{C}_{\mathrm{n}} \mathrm{H}_{2 \mathrm{n}}$ & 比較的純粋な液体，F の存在に注目 \\
\hline \multirow{3}{*}{$\begin{array}{l}\text { 燃 } \\
\text { 媇 } \\
\text { 性 }\end{array}$} & & $\overline{-}$ & 不燃 & 可燃 & \multirow{3}{*}{$\begin{array}{l}\text { 不燃変圧器に応用できる } \\
\text { 高価（最下行参炤）ではあるか，極端に } \\
\text { 火気を嫌う用途に好適 }\end{array}$} \\
\hline & 引火点 & ${ }^{\circ} \mathrm{C}$ & & 145 & \\
\hline & 燃煜速度 & $\mathrm{cm} / \mathrm{s}(\mathrm{JIS})$ & & 0.52 & \\
\hline \multirow[t]{5}{*}{ 物 } & 沸点 & ${ }^{\circ} \mathrm{C}$ & 101 & $280 \sim 450$ & 高温では加圧が必要（気化防止） \\
\hline & 動粘度 & $\mathrm{cSt}$ & 0.8 & 14.1 & 大流速冷却に適し循環系で有効 \\
\hline & 密度 & $\mathrm{g} / \mathrm{cm}^{\mathrm{s}}$ & 1.76 & 0.86 & 䋓緣物が浮き易い \\
\hline & 比熱 & $\mathrm{cal} / \mathrm{g} \cdot{ }^{\circ} \mathrm{C}$ & 0.25 & 0.45 & 熱容量が同程度 \\
\hline & 表面張力 & $\mathrm{dyn} / \mathrm{cm}$ & 14 & 46 & 固体表面を濡らして広がる傾向が強い \\
\hline \multirow{4}{*}{$\begin{array}{l}\text { 電 } \\
\text { 気 } \\
\text { 特 } \\
\text { 性 }\end{array}$} & 破嬬電压 & $\mathrm{kV}(\mathrm{JIS})$ & 65 & 72 & 変圧器油と同程度（平等電界） \\
\hline & 体䅡抵抗 & $\Omega \cdot \mathrm{cm}$ & $8.4 \times 10^{15}$ & $7 \times 10^{14}$ & 優れた絶縁性能が期待できる \\
\hline & 比誘電率 & $(1 \mathrm{kHz})$ & 1.86 & 2.37 & 複合絶緣の際，液側に電界が集中 \\
\hline & 流動带電度 & $\mathrm{pC} / \mathrm{ml}$ & $0.2 \sim 0.5$ & $40-90$ & 大流速冷却に適し响環系で有効 \\
\hline \multirow{3}{*}{$\begin{array}{l}\text { 溶 } \\
\text { 解 } \\
\text { 量 } \\
\end{array}$} & 水分 & ppm & 11 & $50 \sim 80$ & 優れた絶緣性能が期待できる \\
\hline & 空気 & \multirow{2}{*}{$\begin{array}{c}\mathrm{ml} \text { 気体/ } \\
100 \mathrm{ml} \text { 液体 }\end{array}$} & 38 & 10.8 & \multirow{2}{*}{$\begin{array}{l}\text { 特定の気体に対して忙異常なほど溶解す } \\
\text { るので注意が必要 (脱気・加圧) }\end{array}$} \\
\hline & $\mathrm{SF}_{6}$ ガス & & 769 & 41 & \\
\hline & 五格比概略值 & 対変兏器油 & $85 \sim 90$ & 1 & 非常に高価 \\
\hline
\end{tabular}

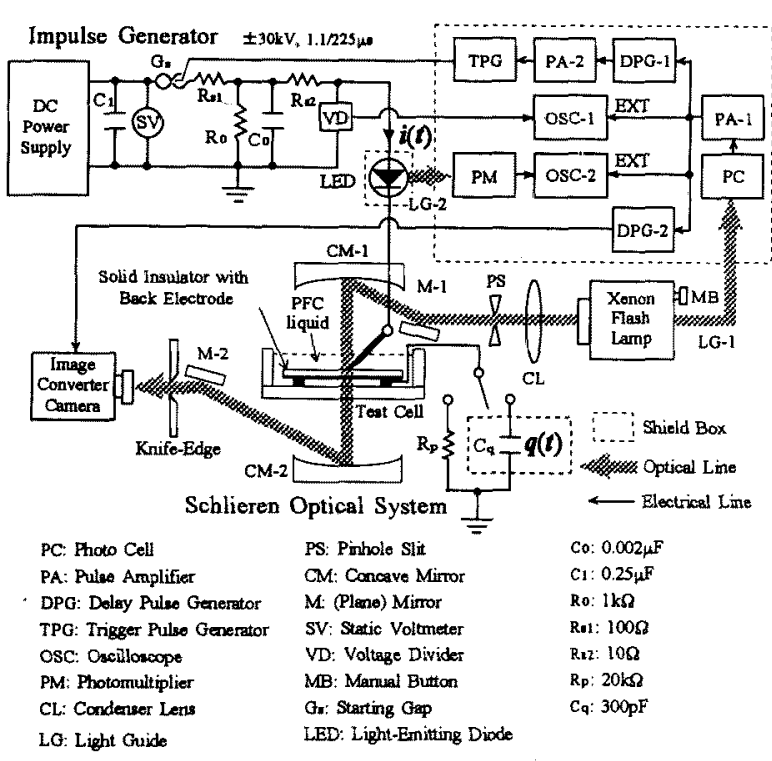

図 1. 实験システムの模成

Fig.1. Schematic diagram of experimental system

測定（ $t$ は電圧印加後の経過時間）は，それぞれ高電圧側 針䉓極に直列に接続された LED および背後平板電極と接 地間に接続されたコンデンサ $C_{q}=300 \mathrm{pF}$ により行った。

図 2 はテストセル内の電極扝よび固体絶縁物の配置を 示す。インパルス電圧（波高值 $V_{m}= \pm 30 \mathrm{kV}$, 波形 1.1 । $225 \mu \mathrm{s})$ が印加される針電極（タングステン製，針端曲率

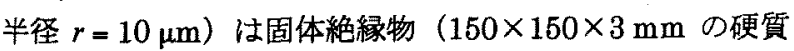
ガラス）上面に軽く接触している。固体絶縁物下面には酸 化インジウム（膜厚 $0.2 \mu \mathrm{m}$, 光透過率 80 90\%) が蒸着 されておりこれを背後平板電極としている。蒸着膜は真鍮 リングに接触し, 真踰リングは保䜠抵抗 $R_{p}=20 \mathrm{k} \Omega(q(t)$ 測定時は $C_{q}$ ) を通して接地されている。現象の撮影には 凹面鏡による垂直型二面対向シュリーレン法を用い，平行 光線は液面に対して垂直に上から下へ透過する。

\section{平行 光 線}

針露極（タングステン製，針端曲率半径 $10 \mu \mathrm{m}$ )

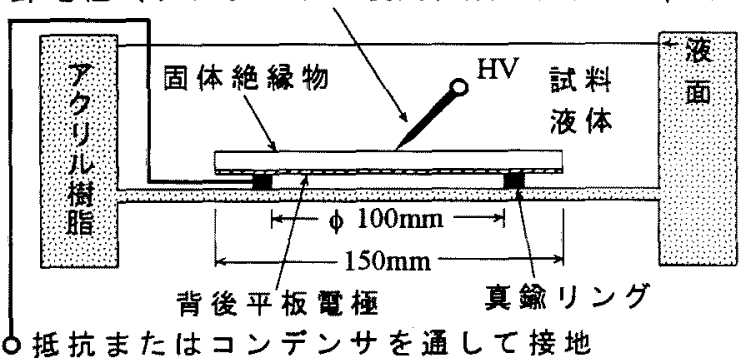

図 2. 電樰および固体絶縁物の配置

Fig.2. Arrangement of electrodes and solid insulator in test cell

\section{4. 実験結果および考察}

〈4・1〉橝性效果図 3 および図 4 は, 針電極にそれ ぞれ正極性および負極性インパルス電在を印加した場合の PFC 液中沿面放電の進展過程を示し，(a) はシュリーレン こま撮り写真, (b) は電流波形 $i(t)$, (c) は電荷波形 $q(t)$ で ある。比較のために同条件で得られた変圧器油中の結果を 図 5, 図 6 に示す。なお，(a) のこま速度は，図 3 (a) が 1 $\times 10^{6} \mathrm{frames} / \mathrm{s}$ (こま間隔 $1 \mu \mathrm{s}$, 露出時間 $0.2 \mu \mathrm{s} /$ frame), 図 4 6 (a) が $5 \times 10^{5} \mathrm{frames} / \mathrm{s}$ (こま間隔 $2 \mu \mathrm{s}$, 露出時間 $0.4 \mu \mathrm{s} /$ frame) である。

図 3 (a)において正極性沿面ストリーマ (正ストリーマ) の進展形状は，図 5 (a) のそれと比較して分岐の極端に少 ない樹枝状で最終進展長も短い。電圧印加直後に見られる (b) の $i(t)$ におけるパルス A と (c)の $q(t)$ における階段状 の増加 $\mathrm{A}$ はともにギャップへの充電に伴ら変化であり, この段階ではまだストリーマは出現・進展していない。そ の後，(a)においては少なくとも $t=2.9 \mu \mathrm{s}$ まで，(b) 拉よ び (c)においては $t=3.8 \mu \mathrm{s}$ まで変化が見られないが, 3.8 
$<t<4.0 \mu \mathrm{s}$ において， $i(t)$ におけるパルス B の立ち上がり と $q(t)$ における階段状の増加 B (これらの B は時間的に 良く一致する) 功認められる。従って, (a)\#2（露出時間 $3.7<t<3.9 \mu \mathrm{s})$ に見られるステップ進展中のストリーマ は $i(t), q(t)$ の変化 B に対忍して進展したことがわかる(一 般に B の発生時刻には $\mu \mathrm{s}$ オーダーのばらつきがある)。 ストリーマは\#3で既に進展を停止しており, 以後時間の 経過とともにストリーマの進展経路に沿って複数のショッ ク波が液中音速（約 $6 \times 10^{2} \mathrm{~m} / \mathrm{s}$ 一定）で伝播する様子も 認められる。
一方，図 4 (a)に示されるブッシュ状の負極性沿面スト リーマ (負ストリーマ) は, 図 3 (a) の正ストリーマと比 較して進展継続時間が長く最終進展長が短い。また, 正ス トリーマに見られたステップ状の進展や，これに対応する $i(t)$ および $q(t)$ の変化は明瞭には認められないが, 図 $4(\mathrm{~b})$ 之(c) の比較から， $i(t)$ におけるパルスの発生と $q(t)$ におけ る微小な階段状增加との間には良い時閒的対応が見られる。 このことから，負ストリーマの場合にも針端近傍の固体絶 縁物表面において，極めて小規模なステップ進展あるいは 枝分かれが生じたものと考えられる。なお，負ストリーマ

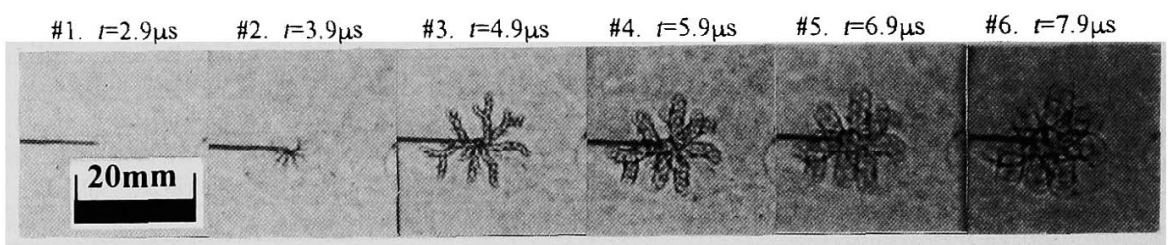

(a) シュリーレンこま撮り写真 $\left(1 \times 10^{6} \mathrm{frames} / \mathrm{s}\right)$

Schlieren framing photograph

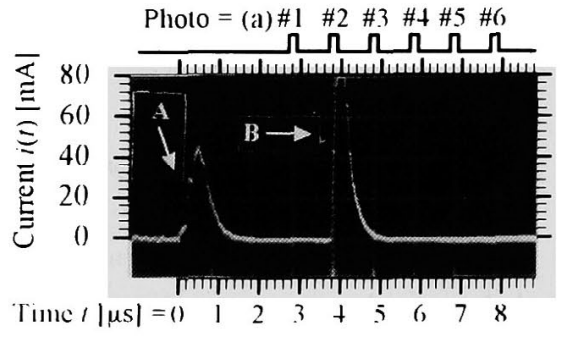

(b) 電流波形 Current waveform $i(t)$

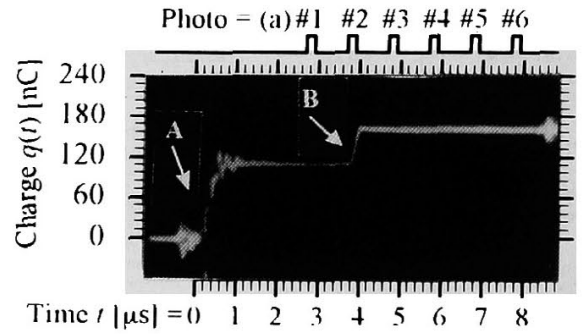

（c）電荷波形 Charge waveform $q(t)$

図 3. PFC 液中正極性治面ストリーマの進展 (1) $\quad\left(V_{m}=+30 \mathrm{kV}\right)$

Fig.3. Propagation of positive streamer on solid insulator in PFC liquid (1)

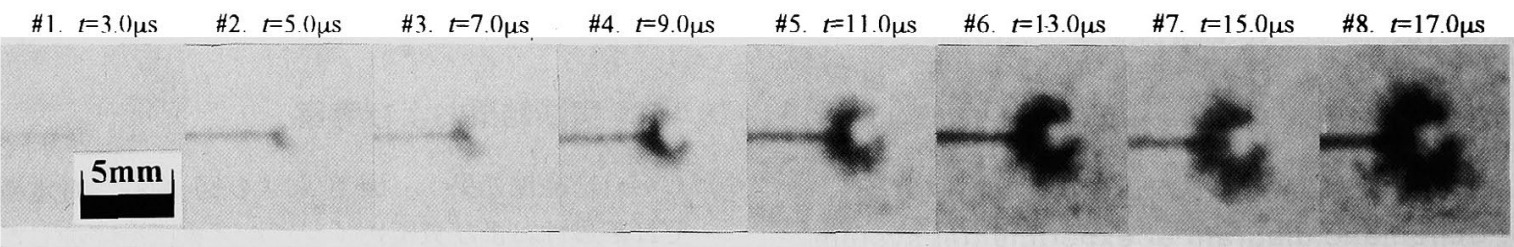

(a) シュリーレンこま撮り写真 $\left(5 \times 10^{5}\right.$ frames/s) Schlieren framing photograph

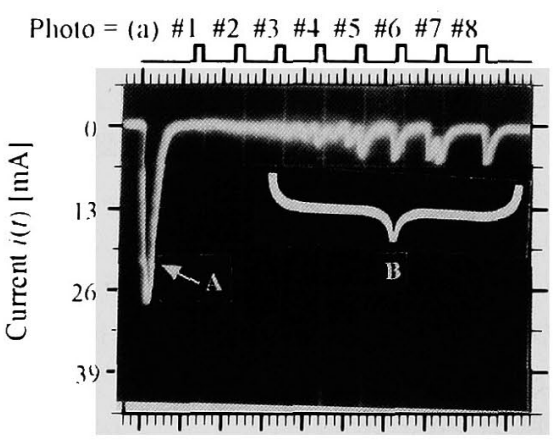

Time ||$\mu s \mid=1) \quad 2+6 \quad 8 \quad 10 \quad 12 \quad 14 \quad 16 \quad 18$

(b) 電流波形 Current waveform $i(t)$

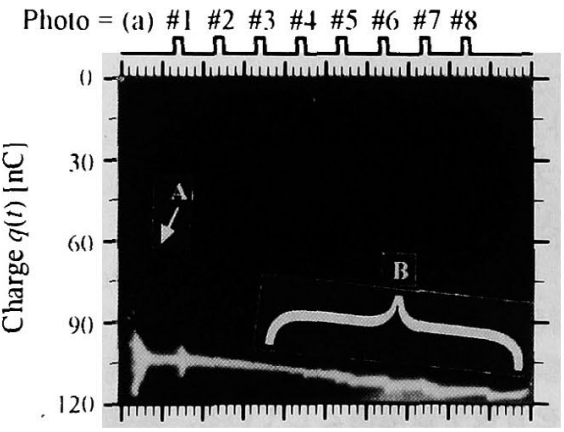

Timc $1|\mu \mathrm{s}|=0 \quad 2+6 \quad 8 \quad 10121+161820$

(c)電荷波形 Charge waveform $q(t)$

図 4. PFC 液中負極性治面ストリーマの進展 $\left(V_{m}=-30 \mathrm{kV}\right)$

Fig.4. Propagation of negative streamer on solid insulator in PFC liquid 


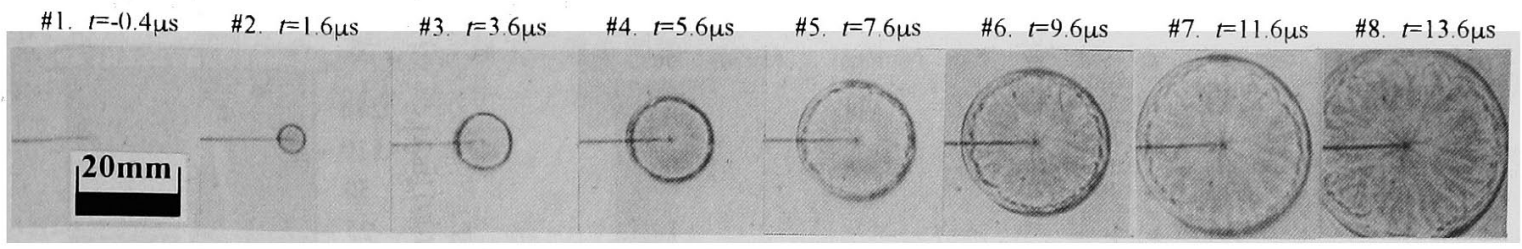

(a) シュリーレンこま撮り写真 $\left(5 \times 10^{5}\right.$ frames/s) Schlieren framing photograph
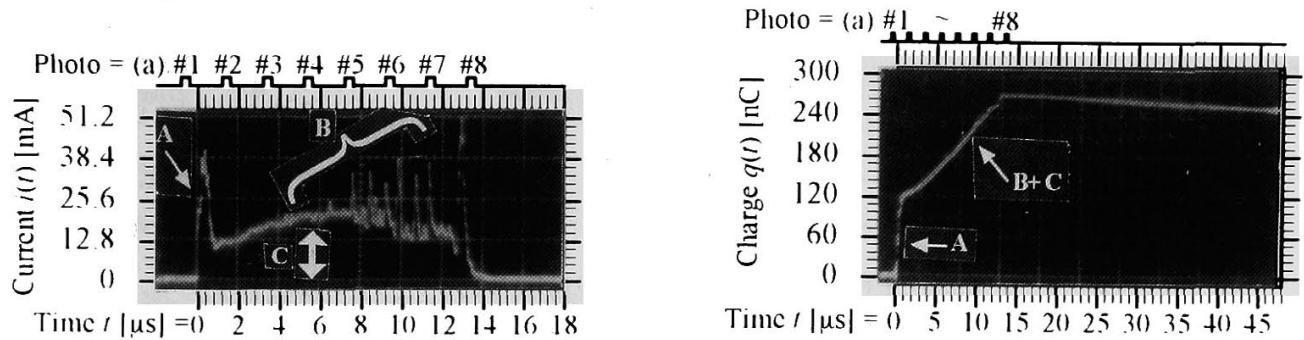

(b) 電流波形 Current waveform $i(t)$

(c) 電荷波形 Charge waveform $q(t)$

図 5. 变圧器油中正極性治面ストリーマの進展 $\left(V_{m}=+30 \mathrm{kV}\right)$

Fig.5. Propagation of positive streamer on solid insulator in transformer oil
\#1. $t=-(1) .5 \mathrm{us} \quad \# 2 . t=1.5 \mathrm{us}$
\#3. $t=3.5$ s
\#4. $t=5.5 \mu \mathrm{s}$
\#5. $t=7.5 \mu \mathrm{s}$
\#6. $t=9.5 \mu \mathrm{s}$
\#7. $t=11.5 \mu \mathrm{s}$
\#8. $t=13.5 \mu \mathrm{s}$

$20 \mathrm{~mm}$

(a) シュリーレンこま撮り写真 $\left(5 \times 10^{5} \mathrm{frames} / \mathrm{s}\right)$

Schlieren framing photograph

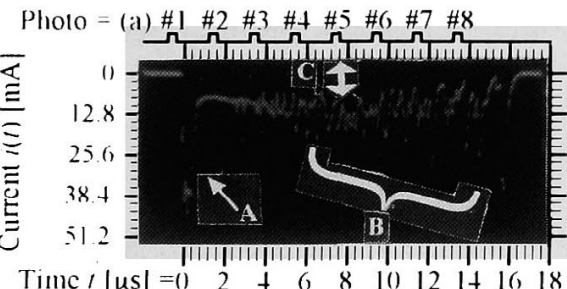

(b) 電流波形 Current waveform $i(t)$

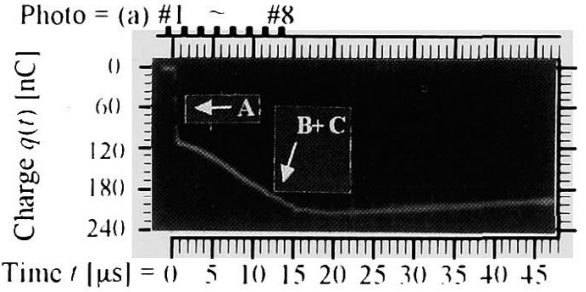

(c) 電荷波形 Charge waveform $q(t)$

図 6. 変圧器油中負極性沿面ストリーマの進展 $\left(V_{m}=-30 \mathrm{kV}\right)$

Fig.6. Propagation of negative streamer on solid insulator in transformer oil

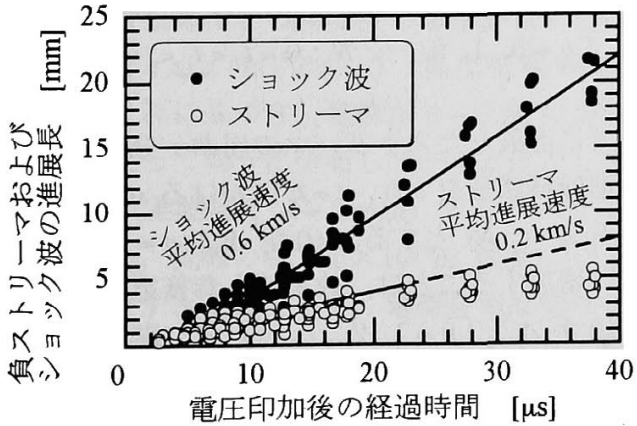

図 7. PFC 液中負極性治面ストリーマの進展特性

Fig.7. Propagation characteristics of negative streamer on solid insulator in PFC liquid
は針端から全方向均等に進展するとは限らず，図 4 の場 合，(a) \#4〜\#8 において針端近傍右側の白い部分にはスト リーマが進展していない。図 7 は，負ストリーマおよび ショック波の進展長一時間特性を示す。負ストリーマの平 均進展速度は $2 \times 10^{2} \mathrm{~m} / \mathrm{s}$ 程度で, これは変圧器油中の $(7.6$ $\sim 9.2) \times 10^{2} \mathrm{~m} / \mathrm{s}^{(12)}$ と比べて著しく小である。

図 5 , 図 6 の (b) $i(t)$ において, 電圧印加直後に見られ る充電電流 A と，比較的滑らかな放電電流のベーースレベ ル C にストリーマの進展に伴う不規則なパルス群 B が重 盢している様子が認められる(12)。両図 (a)においてストリ 一マは連続的に進展しているように見えるが，これは頻繁 に多数回生じた微小ステップ進展あるいい枝分かれの総和 


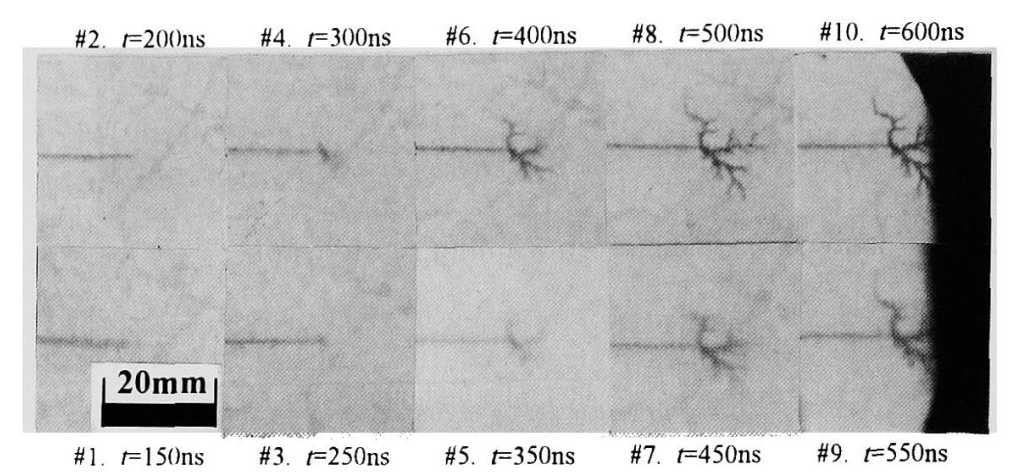

(a) シュリーレンこま撮り写真 $\left(2 \times 10^{7} \mathrm{frames} / \mathrm{s}\right)$ Schlieren framing photograph

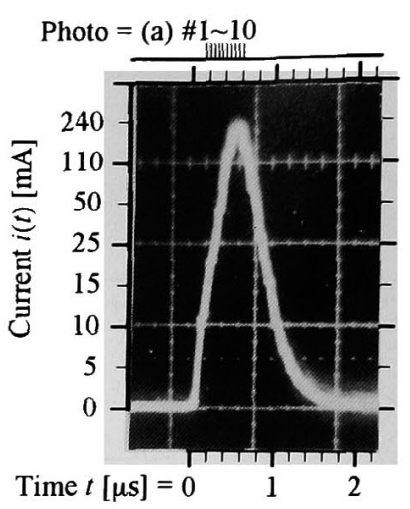

(b) 電流波形

Current waveform $i(t)$

図 8. PFC 液中正極性沿面ストリーマの進展 (2) $\quad\left(V_{m}=+30 \mathrm{kV}\right)$

Fig. 8. Propagation of positive streamer on solid insulator in PFC liquid (2)

であると考えられる。また, 両図 (c)において, $i(t)$ の変 化に対応して $q(t)$ が変化している様子が認められる。これ に対し PFC 液の場合（図 3, 図 4) では, $i(t)$ および $q(t)$ において C に相当する成分が極めて小であり，ギャップ 間を流れる放電電流の平均レベルが小さい。

〈4・2〉正ストリーマのステップ進展 図 3 に見られ るように, PFC 液中正極性沿面ストリーマ（正ストリー マ）の特徵はステップ進展である。図 8 は, 図 3 と同条 件で，単一電流パルスの立ち上がり時間に対応するストリ ーマのステップ進展過程をより高速度 $\left(2 \times 10^{7} \mathrm{frames} / \mathrm{s}\right.$,

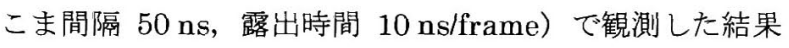
の一例を示す。この場合, 電圧印加直後のギャップへの充 電時間に正ストリーマが既にステップ進展しており，(b) の $i(t)$ に扔いては, 充電電流パルスに正ストリーマのステ ップ進展に伴う電流パルスが重畳している（図 3 (b) の記 号を用いると, 充電電流 $\mathrm{A}$ に発生時刻が変動する B が重 なり，1つの大きなパルスとして示されている)。また，

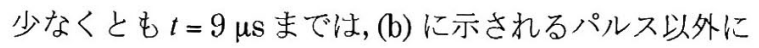
$i(t)$ における変化が見られない。

(a) と (b) との比較から, 正ストリーマは $i(t)$ のパルス立

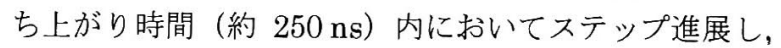
そのパルスのピーク時刻でほぼ進展を停止している。その 後, ストリーマの進展経路に沿って図 3 (a) と同様複数の ショック波が発生し, 時間経過とともに伝播する様子が確 かめられている。正ストリーマのステップ進展に対する平 均進展速度は, 例えばこの場合, $(4.8 \sim 5.2) \times 10^{4} \mathrm{~m} / \mathrm{s}$ と なり，他 40 個の実験データに対しても $10^{4} \mathrm{~m} / \mathrm{s}$ のオーダ 一の值が得られた。これは同条件での変圧器油中における 正ストリーマの平均進展速度 $(1.20 \sim 1.30) \times 10^{3} \mathrm{~m} / \mathrm{s}^{(12)}$ 上 比較して著しく大である。

このように正ストリーマのステップ進展と $i(t)$ および $q(t)$ の変化との時間的対応が明確でかつ単純なことから,
PFC 液中における正ストリーマの進展に対して数式によ るモデル化および詳細な検討が可能である。ここでは，モ デルの複雑化を避けるため図 8 のように電圧の波頭で進 展する場合は例外とし, 図 3 のように電圧が波高值に達 した後の波尾で現象が出現する一般的な正ストリーマの進 展を考える。また，正ストリーマが複数回ステップ進展す る場合 ${ }^{(13)}$ も考慮する。

本実験で用いたインパルス電圧は, 沿面放電の進展継続 時間においてほとんど減衰しないことからステップ電圧と 仮定し, 単位ステップ関数 $u(t)$ を用いて $V_{m} u(t)$ と表すこ とができる。液浸の針電極一固体絶縁物一平板電極系は, その幾何学的配置および使用した固体・液体絶縁物による 固有の静電容量を持つ。これに電圧 $V_{m} u(t)$ が印加され, 電界強度がある限界を超えると針端から部分放電が開始し, 媒質である液体の絶縁破壞により固体絶縁物の表面に沿っ て正ストリーマが進展する。

正ストリーマのステップ進展に伴う $i(t), q(t)$ および後 で定義する物理量のうちストリーマのステップ進展に対応 する成分に，その発生の順に 1 番目から $N$ 番目まで番号 $n$ を付け, 便宜上充電成分を 0 番目とする。 $i(t)$ および $q(t)$ がストリーマの第 $n$ ステップ進展に対応して変化する時刻 は実験の結果一致しており（図 3 (b) B)，これをステップ 進展時刻 $t_{n}\left(n=0,1,2, \cdots, N ; 0=t_{0}<t_{1}<\cdots<t_{N}\right)$ と定 義する。

時刻 $t$ までに進展したストリーマの屈曲・分岐を考虑し た累積放電進展経路長を $s(t), t=t_{n}$ における $s(t)$ の変化量 を $\Delta s_{n}(n=1,2, \cdots, N)$ とする。 $s(t)$ が $\Delta s_{n}(n=1,2, \cdots, N)$ ずつ階段状に増加することは，放電路と背後電極との間の 静電容量 $C(t)$ が $\Delta C_{n}(n=1,2, \cdots, N)$ ずつ階段状に増加 することを意味する。便宜上ギャップ固有の静電容量を $\Delta C_{0}$ とする。同様に $q(t)$ が $\Delta q_{n}(n=0,1,2, \cdots, N)$ ずつ 階段状に増加すると, $q(t)$ 測定用コンデンサ $C_{q}=300 \mathrm{pF}$ の端子電圧が $\Delta V_{n}=\Delta q_{n} / C_{q}(n=0,1,2, \cdots, N)$ ずつ上昇 
するため, 針電極一背後平板電極間の電圧 $V(t)$ は $V_{m}$ から $\Delta V_{n}$ ずつ階段状に降下する。従って，以上の值を理想的な 素子の值として扱えると仮定すればステップ倠展は

$$
\begin{aligned}
s(t) & =\sum_{n=1}^{N} \Delta s_{n} u\left(t-t_{n}\right), \quad C(t)=\sum_{n=0}^{N} \Delta C_{n} u\left(t-t_{n}\right), \\
q(t) & =\sum_{n=0}^{N} \Delta q_{n} u\left(t-t_{n}\right)=C(t) V(t)=C_{q}\left[V_{m} u(t)-V(t)\right], \\
V(t) & =V_{m} u(t)-\sum_{n=0}^{N} \Delta V_{n} u\left(t-t_{n}\right)=V_{m} u(t)-\frac{q(t)}{C_{q}} \\
& =\frac{C_{q}}{C(t)+C_{q}} V_{m} u(t), \Delta V_{n}=\frac{\Delta q_{n}}{C_{q}}, \\
\frac{V_{m}}{q(t)} & =\frac{1}{C(t)}+\frac{1}{C_{q}}, \quad \frac{V_{m}}{\Delta q_{0}}=\frac{1}{\Delta C_{0}}+\frac{1}{C_{q}}
\end{aligned}
$$

と表せる。ただし, 実際の各波形の $t=t_{n}$ における変化の 形状は理想的なステップ関数とは若干異なり，各ステップ の立ち上がりには有限の微小時間を要する。図 9 は (1) 式 を図式的に示したものである。また， $n=0$ の各值は用い た装置および条件に依存するものであり，既知数と実験結 果を(1) 式に適用すると，本実験の場合はおよそ $\Delta C_{0}=4$ $\mathrm{pF}, \Delta q_{0}=120 \mathrm{nC}, \Delta V_{0}=400 \mathrm{~V}$ となる。(1) 式からストリ 一マのステップ進展過程は $C(t)$ の階段状增加過程と解釈 できる。すなわち，電極を通して外部から注入されるエネ ルギーによって, 複合 (固体一液体) 絶縁系がその空間的 な秩序を維持することができなくなった場合に, 誘電率が 低い液体側に電界が集中して部分的破媼が生し，放電路と 対電極との間の静電容量が一時的に增加する。それによっ て外部からのエネルギーを系の内部で保持し，また次々に 注入されるエネルギーが放電レベルに達すると, 随時この 過程を繰り返すものと考えられる。

図 10 は, 複数の結果から得られたステップ進展長 $\Delta s$ (横 軸）とそれに対応する電荷量の変化 $\Delta q$ （繸軸）との比例 関係を示し，最小二乗法により得られた図中の直線の傾き $\lambda=\Delta q / \Delta s=0.86 \mathrm{nC} / \mathrm{mm}$ （比例定数）は 1 回のステップ進 展におけるストリーマの単位長当たりの平均電荷量を表す。

大垣氏らは，ストリーマを細い管状の導体（半径 $r$ ）と 考え, 背後電極を持つ固体絶縁物（比誘電率 $\varepsilon_{r}$, 厚さ $d$ ) 表面に沿って進展するストリーマについて報告し(17)，ス トリーマが背後電極との閒に持つ単位長当たりの静電容量 を $\lambda / V(t)=2 \pi \varepsilon_{0} \varepsilon_{r} / \ln (2 d / r)$ (真空誘電率 $\left.\varepsilon_{0}\right)$ と近似 している。これに基づき，電荷が $\lambda=0.86 \mathrm{nC} / \mathrm{mm}$ で全放 電経路にわたって均一に分布していると仮定して単純に計 算 $\left(\varepsilon_{r}=6.1\right.$ (実測値),$\left.d=3 \mathrm{~mm}\right)$ すると $r$ は $10^{-8} \mathrm{~m}$ のオ 一ダーとなり，既報の值 $\left(5 \times 10^{-6} \mathrm{~m}\right.$ 程度) (1) と比へてあ まりにも小さすぎる。従って，電荷分布は均一ではなく， 常に解離・励起・電離が進行しているストリーマ先端に空 間電荷などの電荷が偏在しているのではないかと考えられ る。また，rのオーダーが $10^{-6} \mathrm{~m}$ であると仮定すれば，ス トリーマ先端の電荷密度 $\lambda$ は, $0.86 \mathrm{nC} / \mathrm{mm}$ よりも大きな $1.1 \sim 1.6 \mathrm{nC} / \mathrm{mm}$ 程度の值となる。これが変圧器油中の残
留電荷量の測定から得られた $1.5 \sim 3.0 \mathrm{nC} / \mathrm{mm}^{(18)}$ と一部重 なることは興味深い。この比較で変圧器油中の入の方が 大きいのは, 変圧器油中ではストリーマが管状というょり はむしろ放射状に密に分岐しながら進展するため, 全体と して比較的円板状に近い形状となり $C(t)$ が大きくなるか らではないかと考える。実際，図 3 および図 5 に見られ るように, 変圧器油中に比へ $\mathrm{PFC}$ 液中を進展するストリ 一マの分岐が少なく最終進展長が短いことは，放電により 液中に注入される電荷量が少なくなり，特に不平等電界を 念頭に置いた PFC 液による絶縁設計に対しては望ましい と考えられる。

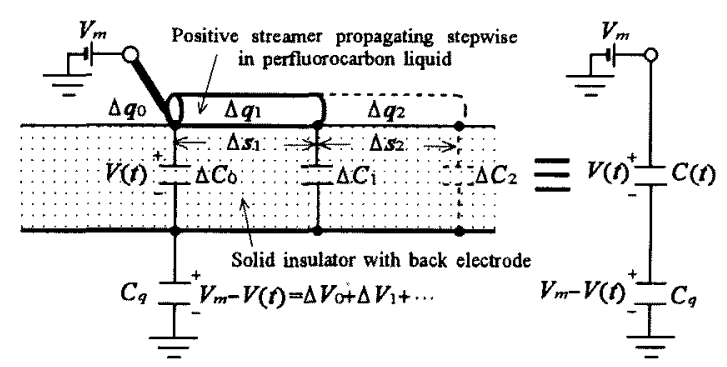

図 9.PFC 液中正極性治面ストリーマのステップ進展モデル Fig.9. Step propagation model of positive streamer on solid insulator in PFC liquid

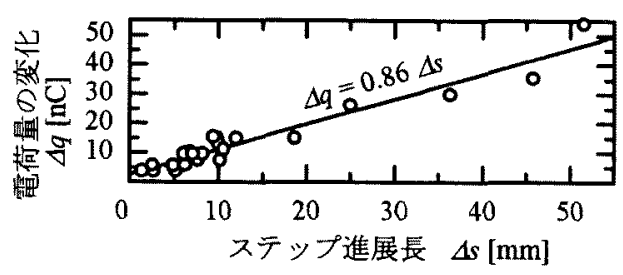

図 10. PFC 液中正極性治面ストリーマのステップ進展特性 Fig.10. Step propagation characteristics of positive streamer on solid insulator in PFC liquid

以上の結果， $\mathrm{PFC}$ 液中における正極性沿面放電の進展 特性は, 変圧器油中のそれと比べて著しく異なることが認 められた。これについては, 前に述べた PFC 液の主成分 であるパーフルオロオクタン $\mathrm{C}_{8} \mathrm{~F}_{18}$ を構成する $\mathrm{F}$ の化学的 性質，すなわち(1) 電離および解離に大きなエネルギーを 必要とすること, (2) 電離・解離により荷電粒子が生成さ れたとしても，F の強い電子親和性により周囲の電子に対 して非常に大きな吸引作用を及ぼすこと等の原因が考えら れ，これらによって，PFC 液中での放電進展特性，特に 変王器油中のそれとの差異について説明することができる のではないかと考えられる。

表 2 は, PFC 液中と変圧器油中に扔ける沿面放電の進 展特性を比較したものである。PFC 液中では変圧器油中 に比べ，両極性ともにストリーマは伸びにくい。 
表 2. PFC 液中と変圧器油中における治面ストリーマの進展特性（ $V_{m}= \pm 30 \mathrm{kV}$, 室温大気圧）

Table 2. Propagation characteristics of streamer on solid insulator in PFC liquid and transformer oil

\begin{tabular}{|c|c|c|c|c|c|}
\hline \multirow[b]{2}{*}{ 液体 } & \multirow{2}{*}{$\begin{array}{l}\text { 針電極の } \\
\text { 電圧極性 }\end{array}$} & \multicolumn{3}{|c|}{ 沿面ストリーマ } & ショック波 \\
\hline & & $\begin{array}{c}\text { 平均進展速度 } \\
(\mathrm{km} / \mathrm{s})\end{array}$ & $\begin{array}{c}\begin{array}{c}\text { 平均進展長 } \\
(\mathrm{mm})\end{array} \\
\end{array}$ & 進展形状・特徵 & $\begin{array}{c}\text { 平均進展速度 } \\
(\mathrm{km} / \mathrm{s})\end{array}$ \\
\hline \multirow{2}{*}{ PFC 液 } & 正 & $※ 1$ & $5 \sim 15 ※ 2$ & 樹枝状 & \multirow{2}{*}{0.6} \\
\hline & 負 & 0.2 & $3 \sim 6$ & ブッシュ状 & \\
\hline \multirow{2}{*}{ 変圧器油 } & 正 & $1.20 \sim 1.30$ & $>20$ & フィラメント状 & \multirow{2}{*}{$1.37 \sim 1.42$} \\
\hline & 負 & $0.76 \sim 0.92$ & 16 & フィラメント状 & \\
\hline
\end{tabular}

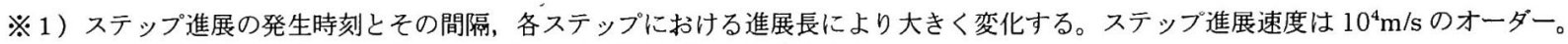
※2）ステップ進展の発生回数, 各ステップにおける進展長により変化する。

\section{5. あとがき}

PFC 液中における沿面放電の進展過程を, 針電極一固 体絶縁物一背後平板電極系を用いてインパルス電圧条件下 において詳細に観测し，既に得られている変圧器油中にお ける結果と比較検討を行った。以下にその結果を要約する。

(1) PFC 液中沿面放電においても極性効果が認められた。

(2) 変圧器油の場合に比べて，PFC 液中では正極性沿面 ストリーマ (正ストリーマ) は枝分かれの極端に少ない樹 枝状でステップ進展する。また，両極性ともにストリーマ は変圧器油中より伸びにくく, 放電電流の平均レベルが極 めて小さい。

(3) 正ストリーマのステップ進展は，電流波形における 不規則なパルスおよび電荷波形における階段状増加と時間 的に対応する。

(4) 正ストリーマのステップ進展における単位長当たり の平均電荷量は $0.86 \mathrm{nC} / \mathrm{mm}$ 程度であり,これは従来の 結果とほぼ一致する。

最後に，卒業研究として本実験およびデー夕整理に従事 された大場満，菅原克彦の両君に心から感謝する。

(平成 9 年 12 月 1 日受付, 平成 10 年 1 月 28 日再受付)

\section{参考文献}

(1) 電学誌 : 109,604 (平元-7)；109, 929 (平元-11).

（2）向山・高术・川嶋・梅根・桧垣・遠藤・坂元：「275kV 100MVA 三 相不然変圧器の実規模試作」平成元年電気学会全大, No.820 (1989).

（3）山形・緒志・大久保・寺西・池田・村山・柳父：「セパレートガス絶 䋑変圧器の絶縁技術開発」平成元年電気学会全大, No.819 (1989)

（4）小林・高木・遠藤・川嶋：「パーフルオロカーボン液の絶縁特性」平 成 2 年電気学会全大, S.2-6 (1990)

（5）高木・古川・遠藤・白根・鎌田・檜垣 ・ 川嶋 :「パーフルオロカーボ 液の絶縁破境特性」電気学会放電, 絶縁材料共同研資, ED-88-126, EIM-88-104 (1988).

（6）高木・古川・遠藤・白根・鑇田・檜垣・川嶋：「パーフルオロカーボ ン液及びその液浸複合絶縁系の絶縁破罗特性」第 22 回電気絶縁シ ンポジウム, II-7 (1988).

（7）高木・白根・逗藤・川嶋：「パーフルオロカーボン液浸絶縁系の絶縁 特性」電気学会絶縁材料研資, EIM-90-80 (1990).

（8）宮城・堀井・篗田・杉本：「パーフロロカーボン液の複合絶緑特性」 電気学会静止器研冾, SA-90-59 (1990)

（9）宮城・堀井・窪田・杉本：「パーフロロカーボン液におけるコイル間 複合絶縁モデルの雷インパルス特性」電気学会高電圧研資, HV-91 93 (1991)

（10）宮城・堀井・杉本：「液冷却不燃変圧器における液体一固体絶縁物の 絶縁特性」電学論 $\mathrm{B}, 115,312$ (平 7-4)

（11）阿部・鵧沢・小出・仲神：〔新不燃液体の絶縁破壊特性」電気学会放 電研資, ED-88-127 (1988).
（12）中尾 - 伊藤 - 岡 - 空 - 酒井 - 田頭：「油中インパルス沿面放電の進展 に伴う密度変化と粉像」電学論 $A, 109,189$ (平元-5)

（13）脇本・伊藤・尾・宮城・酒井・田頭：「パーフルオロカーボン液中 沿面放電の進展 (2)」電気学会放電研資, ED-97-79 (1997).

（14）脇本・伊藤・ 中尾・宮城・酒井・田頭：「パーフルオロカーボン液中 沿面放電の進展 $(4)$ 」平成 9 年度電気学会 $\mathrm{A}$ 部門総合研究会, 放電 研資, ED-97-207 (1997).

（15） 日本学術振興会フッ素化学第 155 委員会編：「フッ素化学入門一基 喏と実験法一」日刊工業新聞社 (1997).

（16）中尾・成瀬・伊藤・鈴木・酒井・田頭：「油中沿面放電の進展に及ほ 寸固体絶縁物の厚さ・種類の影響」電学論 $\mathrm{A}, 116,849$ (平 8-10).

（17）大垣・角田：「油中正極性沿面放電の進展特性」電学論 A, 103，601 (昭 58-11).

（18）大久保・池田・本多：「油中沿面放電の進展特性」電気学会放電研資， ED-80-67 (1980)

中尾 好隆 (正員) 昭和 12 年 7 月 15 日生。 37 年 3

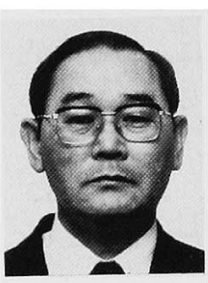
月北海道大学工学部電気工学科卒業。38 年 5 月同大学工業教員羑成所勤務。 43 年 4 月室蘭工業大学勤務, 現在に至る。工学 博士。照明学会,放電研究グループ会員。

脇本 聖 (学生員) 昭和 48 年 4 月 2 日生。平成 8

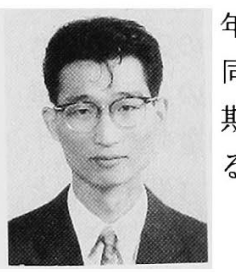
年 3 月室蘭工業大学電気電子工学科卒業。 同年 4 月同大学大学院工学研究科博士前 期課程電気電子工学専攻入学, 現在に至 る。

宮城 克徳 (正員) 昭和 32 年 2 月 11 日生。 55 年 3 月室蘭工業大学電気工学科卒業。57 年同 大学大学院工学研究科修士課程修了。同 年 (株) 明電舎入社, 現在に至る。主と して, 変圧器の絶縁技術・開発および高 電圧計測に関する業務に従事。 


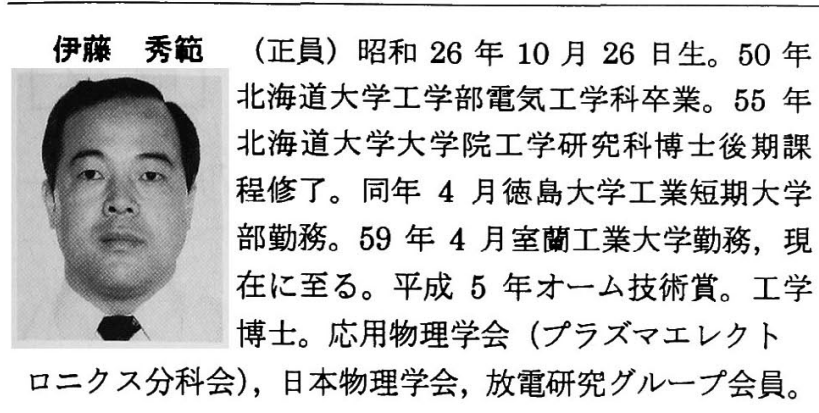

酒井 洋輔 （正員）昭和 19 年 7 月 28 日生。 48 年 3 月北海道大学大学院工学研究科博士課程 修了。同年北海道大学工学部勤務。59 年 4 月北海道大学医療技術短期大学勤務。 62 年 5 月北海道大学工学部勤務, 現在に至 る。工学博士。照明学会, 日本物理学会, 応用物理学会, 放電研究グループ会員。

田頭 博昭 (正員) 昭和 8 年 1 月 13 日生。 33 年 3

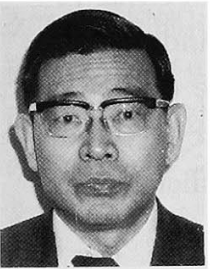
月北海道大学工学部電気工学科卒業。36 年同大学大学院博士課程中退。同年北海 道大学工学部勤務。平成 8 年 4 月, 北海 道工業大学勤務, 現在に至る。平成 3 年 照明学会論文賞。Ph.D (英国リバプール 大学)。工学博士。照明学会, 日本物理学 会, 応用物理学会 (プラズマエレクトロニクス分科会), プラズマ核融合学会, 溶接学会, 放電研究グループ会員。 